\title{
Plant Development, Stage of Maturity and Nutrient Composition
}

\author{
M.R. KILCHER
}

\section{Abstract}

Declining nutrient content of native and seeded pasture plants with advancing growing stages are discussed. All plant types display this regression in nutritive value but to different degrees, different rates, and varying patterns. The situation is further aggravated by the concomitant increase in lignin and other fibrous properties which precludes maximum digestibility of an already declining nutrient level in the plant.

Countless observations by generations of people through research measurements, performance trials, and producer experience have contributed to the almost irrefutable recognition and acceptance of the fact that the nutrient composition of early plant growth exceeds that of the same plants with advancing maturity. We need to be reminded of this on occasion as we streak along in a world of accelerating automation and technological change. In the face of this turmoil we should review and reflect on some of the basic knowledge that we have come to take for granted.

\section{Influencing Factors}

A multiplicity of factors affects the rate of change in nutrient composition with advancing plant development and maturity stages. Thesc factors may include any one or a combination of the following: plant type, climate, season, weather, soil type and fertility, soil moisture, leaf stem ratio, physiological and morphological characteristics and others, and may vary with annuals vs. perennials, grasses vs. legumes, etc.

By themselves, nutrient composition levels are not necessarily the only criterion in evaluating the nutritive value of plants (Cook and Harris 1950, 1979; Joyce and Brunswick 1975; Prates et al. 1975; Reid et al. 1959; and Stobbs 1975). What they mean to the animal and that animal's response is what is important in the end. Therefore, it seems logical to consider plant nutrient composition as only one consideration in the human food chain that progresses from soil to plants to animals to humans. For these reasons plant nutrient composition cannot be discussed in isolation, particularly in isolation of the animal it feeds.

The inherent nutrient composition within plants varies between crops, between what are classified as cool-season or warm-season plants, temperate zone and tropical crops, and other influencing parameters. It is evident, however, that most plants show a similarity in declining nutrient composition with advancing development towards maturation (Cogswell and Kamstra 1976; Ishiguri 1975; Kamstra 1973; Rodgers et al. 1967; Rama et al. 1973; Stubbendieck and Foster 1978). In an oversimplified classification the important nutrients are found as proteins, carbohydrates, and fats. The utilization of these by animals is referred to as the digestible energy (DE) nutritive value of the plant.

\section{Some Examples}

Over a 26-week period it was shown that the crude protein in tropical legumes declined from 26 to $15 \%$ in the leaves, 12 to $10 \%$ in the stems, and from 19 to $13 \%$ in the whole plant (Siewerdt and

\footnotetext{
Author is with Forage-Pasture Management, Research Station Research Branch, Agriculture Canada, Swift Current, Saskatchewan. S9H 3X2 Canada.

Manuscript received December 10, 1979.
}

Holt 1975). However, all of these levels of the protein constituent are high enough to insure adequacy for the rumen animal. The corresponding in vitro digestible dry matter (IVDDM) values for the leaves, stems, and whole-plant fractions over that 26-week period were from 77 to $74 \%, 63$ to $59 \%$, and 73 to $64 \%$, respectively. This represents good utilization and convertibility of plant material.

It should be borne in mind, however, that performance with legumes is much more satisfactory than with grasses. Legumes contain comparatively lower fiber and corresponding lignification than do grasses (Kilcher and Heinrichs 1974; Reid et al. 1959; and Troelsen 1969). Increasing plant fiber invariably results in lower digestibility as well as reduced intake.

Over a 7-week period that included very immature to late bloom alfalfa, sequential 4-day samples showed that the digestible energy of the leaves changed very little, from 74 to $71 \%$. Stems however, changed from 71 to $48 \%$ during the same time. Nutritive parameters differed quite markedly. The nitrogen composition in the leaves declined from $4.7 \%(25 \% \mathrm{CP})$ to $3.6 \%(22.5 \% \mathrm{CP})$. On the other hand, the nitrogen composition in the stems ranged from a high of $2.9 \%(18.1 \% \mathrm{CP})$ to a low of $1.4 \%(8.8 \% \mathrm{CP})$ by late bloom and would probably not be consumed readily as well.

In the same study the phosphorus content declined from 0.35 to $0.26 \%$ in the leaves and from 0.32 to $0.13 \%$ in the stems. These declines combined to contribute to diminishing levels of digestible energy (DE) as the alfalfa advanced towards maturity. The very immature stage of the whole plant had a DE value of $72 \%$ compared to only $55 \%$ at late bloom.

Grass or grass-like plants generally show a large percentage decline in nutrients through developing stages. In addition, they most often do not start out on a plain equal to that of the legumes (Troelsen 1969). Thus the threshold level for nutrient adequacy is more quickly approached and even commonly surpassed so as to make supplementation necessary to maintain production of meat or milk.

Besides nitrogen, and hence protein, most minerals also decline with advancing plant development, including calcium, potassium, zinc, copper, and phosphorus (Rauzi et al. 1969). The latter is usually the most critical to animal growth and productivity. Phosphorus deficiency is almost a universal occurrence in maturing grasses after the inflorescence stage. Few will have a $P$ composition above or even at the National Research Council minimum level for adequacy $(0.17$ to 0.23 .).

Declining nutrient levels in grasses through stage development results in declining utilization. This decline occurs more sharply than it does with legumes. One study showed that in some grasses the digestibility at early leaf was $65.2 \%$, was still $64.7 \%$ at prebloom, and suddenly fell to $56.6 \%$ at early bloom within a very few days (Wallace et al. 1973).

In addition, some species are inherently low in nutrients even at their best. In Georgia, for instance, the grasses making up the pine-wiregrass range have a CP level of only $10 \%$ in April and fall to less than $4 \%$ by October (Lewis et al. 1975). Other plants in that rangeland area include forbs which decline from 16 to $6 \%$ during 
that period of time. Shrubs decline from 12 to $6 \%$. Concurrently, of course, DM digestibility declines from an already low value of $50 \%$ to a meagre $20 \%$.

Mineral composition in mixed swards in Ireland at four progressive stages within 6 weeks showed progressive declines (Wilson and McCorrick 1966). The percentage decline during the 6 weeks was $45 \%$ for N, $35 \%$ for K, 30\% for P, and $8 \%$ for Ca. During the same period, fiber increased by $40 \%$.

Some grasses are similar to legumes in their nutrient composition in very early growth stages. The leaf $\mathrm{CP}$ in smooth bromegrass (Bromus inermis) has been measured at $20 \%$ in early vegetative stages but declined to less than 7\% at maturity (Troelsen 1969). The leaves of a comparative alfalfa (Medicago media) changed from 30 to only $20 \%$ during its seasonal growth stages. Thus, even though a grass may possess some nutrient qualities in excess of the required amount in early growth, they invariably fall quite short of adequacy after inflorescence.

In another study with smooth bromegrass, the measured range in $\mathrm{CP}$ was from a high of $25 \%$ in the early, very immature stage to about $8 \%$ in the mature stage (Kilcher and Troclsen 1973). Cell wall lignin over the same span went from 45 to $60 \%$ in the leaves and from 55 to $70 \%$ in the stems. The resulting digestibility of energy fell from 72 to $57 \%$ in the leaves, from 73 to $35 \%$ in the stems, and from 73 to $47 \%$ in the whole plant.

Cereal grains have somewhat similar nutrient level changes as the plants develop. Cereal grains such as oats (Avena sativa) and winter rye (Secale cereale) are frequently used as fodder for stored, off-season feeds in some localities. They are also used for supplementary grazing. Their development is rapid, and maximum economic utilization depends on increasing the stocking rate to match the almost explosive growth which can occur. In a 9-week period DM yields have been shown to increase from virtually nothing to $5,000 \mathrm{~kg} / \mathrm{ha}$ in an almost linear fashion (Kilcher and Troelsen 1972). In a grazing utilization scheme, the maximum benefits depend on an increasing stocking intensity so that the crop, so to speak, does not get too far ahead of the animals. The CP of leaves of oats was measured as ranging from 30 to $7 \%$ if allowed to mature, while that of stems ranged from 25 to $5 \%$. The energy values for leaves and stems ranged from 3.1 to 2.4 and 3.1 to 1.7 $\mathrm{KCa} / \mathrm{g}$. Whole-plant energy values, however, equated to 3.1 to 2.5 $\mathrm{KCal} / \mathrm{g}$. This was due to the seed that had developed in the latter stages and thereby compensated for the decline, particularly in the stems. The seed increased from 2.5 to $3.2 \mathrm{~K} \mathrm{Cal} / \mathrm{g}$ and also made up nearly half of the total plant yield by maturity.

\section{Precluding Elements}

It would be difficult to find a good literature reference dealing with plant nutrients and corresponding animal response that did not acknowledge the overriding influence of lignin on effective utilization of plant nutrients. This fibrous or lignified component of the plant interferes markedly with the digestible assimilation of positive nutrients including the proteins, fats, and carbohydrates.

As Joyce and Brunswick (1975) recorded, “. . . production depends on both the quantity of food eaten each day and the digestibility of the feed." But it is not just a simple equation of quantity vs. quality. If it were, the consuming animal would simply eat more to compensate for decreasing quality. What actually happens is frequently the compounding occurrence of both a decrease in quantity consumed and a decrease in quality. If the re is an increase in quantity consumed it is usually not sufficient to compensate for the decreasing quality.

The degree of relationship with these two interacting factors has been shown to be strongly related to the extent of lignification. Part of this might well be associated with palatability, in addition to natural chemical tie-up between fiber and other nutrients. Thus the case exists where the digestible nutrients are not only declining with advancing growth stages, but a decreasing proportion of the a mount is being digested. One worker has shown that, even when the $\mathrm{CP}$ remains relatively high through the season, the increasing lignin reduces digestibility (Prates et al. 1975). This was substantiated statistically with a correlation $(r)$ of 0.95 between plant lignin and the intake of digestible organic matter (DOM).

Plants may have as much as $30 \%$ fewer digestible nut rients after blooming, accompanied by another $30 \%$ reduction in intake. Reid ct al. (1959) commented; "It could be argued that the net response was about $60 \%$ greater for the June 11 feed than for the July 9 feed." That is a large difference within a 4-week period of the growing season.

\section{Literature Cited}

Cogswell, C., and L.D. Kamstra. 1976. The stage of maturity and its effect upon the chemical composition of four native range species. J. Range Manage. 29:460-463.

Cook, C.W., and L.E. Harris. 1950. The nutritive value of range forage as affected by vegetation type, site, and state of maturity. Utah Agr. Exp. Sta. Bull. 344, 45 p.

Cook, C.W., and L.E. Harris. 1979. Nutritive value of seasonal ranges. Utah Agr. Exp. Sta. Bull. 472, 55 p.

Ishiguri, T. 1975. Nutritive values in grasses harvested at different cutting stages. Jpn. J. Grassl. Sci. 21(3):154-158.

Joyce, J.P., and L.C.F. Brunswick. 1975. Effect of stage, season, and conservative methods on the nutritive value of lucerne. Proc. N.Z. Soc. Anim. Prod. 35:152-158.

Kamstra, L.D. 1973. Seasonal changes in quality of some important range grasses. J. Range Manage. 26:289-291.

Kilcher, M.R., and J.E. Troelsen. 1972. Contribution and nutritive value of the major plant components of oats through progessive stages of development. Can. J. Plant Sci. 53: 251-256.

Kilcher, M.R., and J.E. Troelsen. 1973. Contribution of stems and leaves to the composition and nutrient content of irrigated bromegrass at different stages of development. Can. J. Plant Sci. 53:767-771.

Kilcher, M.R., and D.H. Heinrichs. 1974. Contribution of stems and leaves to the yield and nutrient level of irrigated alfalfa at different stages of development. Can. J. Plant Sci. 54:739-742.

Lewis, C.E., R.S. Lowery, S.G. Monson, and F.E. Knox. 1975. Seasonal trends in nutrients and cattle digestibility of forage on pine-wiregrass range. J. Animal Sci. 41:208-212.

Prates, E.R., H.L. Chapman, and E.M. Hodges. 1975. Animal performance by steers grazing pensacola bahiagrass pasture in relation to forage production, forage composition and estimated intake. Soil \& Crop Sci. Soc. Fla. 34:152-256.

Rama Rao, M., Leniel H. Harbers, and Ed F. Smith. 1973. Seasonal changes in nutritive value of bluestem pastures. J. Range Manage. 26:419-422.

Rauzi, F., L.I. Painter, and A.K. Dobrenze. 1969. Mineral and protein content of blue grama and western wheatgrass. J. Range Manage. 22:4749.

Reid, J.T., W.K. Kennedy, K.L. Turk, S.R. Slack, G.W. Trimberger, and R.P. Murphy. Symposium on forage evaluation. I. What is forage quality from the animal standpoint? Agron. J. 51:213-216.

Rodgers, J. Daniel, and Thadis W. Box. 1967. Seasonal protein content of four southern mixed prairie grasses. J. Range Manage. 20:177-178.

Siewerdt, L., and E.C. Holt. 1975. Changes in nutritive value of siratra forage with age. Agron. J. 67:544-546.

Stobbs, T.H. 1975. Factors limiting the nut ritional value of grazed tropical pastures for beef and milk production. Trop. Grassl. 9:141-150.

Stubbendieck, J., and Michael A. Foster. 1978. Herbage yield and quality of threadleaf sedge. J. Range Manage. 31:290-292.

Troelsen, J.E. 1969. Quality of hay and roughage. Proc. Can. Forage Crops Symp., p. 1-18.

Wallace, M.H., G.L.M. Chappell, D.G. Ely, W.P. DeWeese, and J.F. Nishimuta. 1973. Nutrient utilization by lambs fed three grass hays harvested at three maturity stages. J. Anim. Sci. 37:298. 